\title{
DEBT RATIO, PERFORMANCE AND CORPORATE VALUES: MANAGERIAL OWNERSHIP VERSUS NON- MANAGERIAL OWNERSHIP
}

\author{
Hartiny Pop Koapaha \\ Fakultas Ekonomi dan Bisnis Universitas Klabat \\ hartinikoapaha@unklab.ac.id
}

\begin{abstract}
This study aims to determine the comparison of debt ratio, company performance and value between companies with managerial ownership and non-managerial ownership companies. The method used in this research is descriptive method and different test using independent sample $t$ - test tools. The number of samples in this study were 180 companies consisting of 14 companies with managerial ownership and 166 non-managerial ownership companies. The results show that the value of debt ratio (debt ratio), financial performance and the value of companies with managerial ownership are higher than non-managerial ownership companies. However, the results of hypothesis testing for significance value when tested with the independent sample test method found that only the value of debt ratio or related debt ratio that there are significant differences between companies with managerial ownership when compared with nonmanagerial ownership companies. For financial performance and firm value variables, it is found higher in companies with managerial ownership, but it was not found to be significantly different when compared to company performance and non-managerial ownership companies.
\end{abstract}

Keywords: Company value, debt ratio, managerial ownership

\section{Introduction}

The purpose of the company is to maximize the wealth of the owner of the company. Any implementation of activities within a company will be carried out on the basis of careful consideration and right so that the decisions taken are right and it will have a good impact on the company's value (Fama \& French, 1998).

Company owners have professional capabilities in managing a company but some are not. There are company owners who delegate company leadership to agents who are considered professionals in managing the company. This agent came to be known as managerial (Jensen \& Meckling, 1976). It was further said that this managerial party would work to increase the value of the company or in other words maximize the wealth of the owner of the company (principal). For this managerial job to run well, the principal must pay a significant amount of money for this professional service. This fee is known as agency cost.

The relationship between the principal and agent will be good if the agent works according to what is expected by the principal. However, there are risks that can occur if the managerial policies or decisions that benefit themselves and not in the interests of the shareholders. This conflict of interest then becomes the basis of agency theory. 
The behavior of the managers who own company stock will certainly be different from those who do not own company stock. If the manager owns shares of a company, then the trend of policies, decisions and behavior taken for the interests of the shareholders as well as for personal interests. However, if the manager does not own shares of a company, there is a possibility that the manager will act contrary to self-interest which is detrimental to shareholders (Christiawan \& Tarigan, 2007).

Several previous studies result that a strong relationship of the managerial ownership with the decisions that are related to business lead by managers. A research conducted by Maftukhah (2013) and Siregar and Yusdiana (2014) found that managerial ownership has a significant influence on a company's debt ratio. Related to firm value, some researchers found that managerial ownership has a relationship and influence on firm value (Sukirni, 2012; Kuswanto, 2006; Putra \& Wirawati, 2013). Some of these results indicate that managers who own company shares will tend to make different business decisions when compared to managers who do not own shares.

Behavior of managers is interesting to study since the results found in the previous studies revealed that managerial ownership has a relationship with various business decisions made by managers then there is a possibility of decisions related to debt ratio, company performance and company value can differ between managers who own shares with managers who do not own the company's shares. Therefore, based on the discussion, the researcher is interested to examine descriptively as to whether there are differences in debt ratio, company performance and company value between companies with managerial ownership, which means managers own company shares compared to non-managerial companies or managers do not have share value in the company of a company. Furthermore, this difference make the differences test by independent sample t-test to indicated whether there are significant differences related to debt ratio, financial performance and company value when compared between companies with managerial ownership and nonmanagerial companies.

\section{Literature Review and Hypothesis Development}

This research is based on agency theory where agents that are being appointed by the principal (shareholders) are required to do everything related to business decision to reach their goal to maximize their wealth of shareholders (Schroeder, Clark, \& Cathey, 2001). However, there is a potential conflict of interest that can become a problem between the agent and the principal (shareholders), when the agents (managers) want to maximize personal profit which is contrary to the original goal that all goals are to maximize shareholder wealth. One reason why this conflict arises is because shareholders cannot fully control all decisions and activities made by managers so that it becomes an opportunity for managers to maximize their personal interests (Schroeder, Clark, \& Cathey, 2001).

Some researches have found that if a manager owns shares of a particular company, then the manager will tend to maximize shareholder wealth and this will also be in harmony with personal interests. Some business decisions and performance of companies related to managerial ownership can be seen in the following discussion:

\section{Managerial ownership and debt ratio}

Managers must have management capabilities in managing the company to maintain the survival of the company. Financial difficulties will lead to bankruptcy which will have an impact on the survival of the company (Meriani \& Krisnadewi, 2012). One of the causes of company 
bankruptcy is due to the level of debt that is too high which is supported by poor management by managers so that the company cannot repay the debt. So managers must be really careful in deciding how much funding comes from debt.

Maftukhah (2013) and Siregar and_Yusdiana (2014) found that if a manager owned shares in a company, the manager's tendency would be be very careful in making decisions regarding debt ratio because the manager do not want financial difficulties which would ultimately harm the shareholders including the managers himself as he also own shares in the company. But there are also researchers who find that managerial ownership has no influence on the debt policies adopted by managers (Santoso, 2001; Yuniarti, 2013). Other researchers have also conducted research that has a link between managerial ownership and debt ratio. (Larasati, 2011; Meriani \& Krisnadewi, 2012; Maftukhah, 2013; Santoso, 2001; Siregar \& Yusdiana, 2014; Yuniarti, 2013).

\section{Managerial ownership and company performance}

One measure to indicated the company's performance is net income. Net income is the difference between income and expenses. The greater profit indicates the higher level of profitability. According to Christiawan and Tarigan (2007) the company's performance will be better if the company's shares are owned by the manager because the manager no longer acts as a paid professional but also as the owner of the company. From the profits generated, it will determine how much dividend will be distributed to shareholders. Managers who own shares will enjoy this dividend distribution. The other researchers who examined managerial ownership related to financial performance are studies that have been conducted by (Lestari, 2019; Hidayat \& Firmansyah, 2017).

\section{Managerial Ownership and Company Value}

The value of the company in this study was measured using the company's market value divided by total assets. A higher score indicates a higher company value, which means how many times the market has valued the company compared to the value of the company's assets. Companies whose managers own shares in a logical company will increase the value of the company because if the value of the company rises then it will increase profits in the form of wealth to him as a manager who is also a shareholder. Several researchers have previously conducted research related to managerial ownership with company value including research conducted by Kuswanto (2006) and Sukirni (2012)_which found there was a significant negative effect between managerial ownership and firm value. Unlike the case with Sumanti and Mangantar (2015), Sumanti and Sukirni (2017) that managerial ownership did not have a significant effect on firm value. Whereas Putra and Wirawati (2013) found that managerial ownership strengthens the relationship between performance and firm value.

\section{Research methods}

This research aims to see a descriptive comparison related to debt ratio, financial performance, and company value between companies with managerial ownership and managerial non-ownership companies. It also will be analyzed by using the independent sample t test different test to see whether there are significant differences related to the three variables, namely debt ratio, financial performance, and the value of the company in companies with managerial ownership 
compared to non-managerial ownership companies. This research period is from 2013-2017. The sample selection is done by purposive sampling method in which several criteria are determined, among others: companies that are consistently registered in the study period, and companies that have complete data related to financial variables in this study. The total sample is 180 companies consisting of 14 companies with managerial ownership and 166 non-managerial ownership companies. The financial data variables in this study can be seen in the following table:

Debt ratio is measured using a debt ratio obtained from total long-term debt divided by total long-term debt plus company equity. The financial performance in this study uses ROA obtained by net income divided by the average total assets of the year $t$ with the previous year. Whereas the variable value of the company show from the market perception is indicate from the value of shares obtained from the volume of stock trading multiplied by the price of shares [hereinafter divided by the total assets of the company]. For managerial ownership category, it show from the ownership statement if the manager in the company has company shares, then it is categorized as a company with managerial ownership, while companies whose managers do not have company shares will be categorized as non- managerial ownership companies.

The first step in the data processing procedure in this study is to group and separate data, namely groups of companies with managerial ownership $(\mu 1)$ and non-managerial ownership companies $(\mu 2)$. Furthermore, the value of the debt ratio variable, financial performance, and company value will make the differences test to see whether there is a significant difference between the group of companies with managerial ownership and non-managerial ownership group of companies. The statistical formula in this study is:

$$
\begin{array}{cc}
\mathrm{H}_{0} & : \mu 1=\mu 2 \\
\mathrm{H}_{\mathrm{a}} & : \mu 1 \neq \mu 2
\end{array}
$$

Hypothesis testing using t-test with two independent sample (independent sample t- test). With a significance level (sig) of 5\%. The decision to accept $\mathrm{H} 0$ is made if the value is significant $>0.05$ and vice versa rejects $\mathrm{HO}$ if the value is significant $\leq 0.05$ (Santoso, 2001).

\section{Results and Discussion}

From the 180 companies that were sampled in this study, 14 companies were companies with managerial ownership and 166 companies were non-managerial ownership companies. This research was conducted in the 2013-2017 research period. Description of research data related to debt ratio, company performance (ROA) and company value can be seen in table 1 below:

Table 1

Statistic Descriptive Data

\begin{tabular}{llllll}
\hline \multicolumn{2}{l}{ OWNERSHIP } & $\mathrm{N}$ & Mean & $\begin{array}{l}\text { Std. } \\
\text { Deviation }\end{array}$ & $\begin{array}{l}\text { Std. Error } \\
\text { Mean }\end{array}$ \\
\hline Debt & Yes & 14 & 0.38 & 0.23 & 0.06 \\
Ratio & No & 166 & 0.24 & 0.32 & 0.25 \\
& Yes & 14 & 0.01 & 0.05 & 0.01 \\
ROA & No & 166 & -0.07 & 2.95 & 0.23 \\
& Yes & 14 & $84,695.07$ & $228,345.66$ & $61,027.95$ \\
Value & No & 166 & $37,150.76$ & $210,755.16$ & $16,357.77$ \\
\hline
\end{tabular}


The average value of the debt ratio for companies with managerial ownership and with nonmanagerial ownership company, show that a percentage of $38 \%$ and $24 \%$, with the source of funds from creditors. Both debt portion sizes are still far from a deficit condition because the value of the debt ratio is still far below the value 1. For company performance measured by ROA found to be higher in companies with managerial ownership compared to non-managerial ownership. Nevertheless, the companies of both groups with managerial ownership and non-managerial ownership both have poor financial performance. If seen from the value of the company measured by market perceptions related to the value of shares, the company with managerial ownership has a higher company value compared to the non-managerial ownership company.

From table 1 it can be seen that the average debt ratio, ROA and Value of companies with managerial ownership are higher than those of companies that do not have managerial ownership. But whether there are significant differences related to debt ratio, company performance and company value between companies with managerial ownership and companies without managerial ownership can be seen in table 2 below:

Table 2 Hypothesis Test Result

\begin{tabular}{llll}
\hline Variable & $\begin{array}{l}\text { Sig.(2- } \\
\text { tail) }\end{array}$ & $\begin{array}{l}\text { Hypothesis } \\
\text { Test }\end{array}$ & Conclusion \\
\hline Debt & 0.04 & $\begin{array}{l}\text { H0 } \\
\text { Rejected }\end{array}$ & $\begin{array}{l}\text { Significant } \\
\text { Differences } \\
\text { No }\end{array}$ \\
Ratio & & $\begin{array}{l}\text { H0 } \\
\text { Accepted }\end{array}$ & $\begin{array}{l}\text { Significant } \\
\text { Differences } \\
\text { No } \\
\text { Significant } \\
\text { Differences }\end{array}$ \\
\hline
\end{tabular}

From the significance value of the hypothesis test results in table 2, it can be seen that only the debt ratio variable has a significant difference between groups of companies that have managerial ownership when compared to non-managerial ownership companies. Although financial performance (ROA) and the value of companies with managerial ownership are higher than companies with non-managerial ownership, the results of hypothesis testing prove that there are no significant differences for these two variables when compared between companies with managerial ownership and non-managerial ownership companies.

From the results of the first hypothesis test, it can be seen that managers in companies with managerial ownership are braver to take risks compared to managers in managerial non-ownership companies who appear to be more careful in taking policies related to debt. This study is different from the research made by Chistiawan and Tarigan (2007) where although the differences in debt ratio were found to be significant differences, the level of debt ratio in companies with managerial ownership is much smaller than the debt ratio of companies with non-managerial ownership. Several references related to managerial ownership and debt policy have been studied previously where they found a relationship between managerial ownership and debt ratio. These studies include research conducted by (Larasati, 2011; Meriani \& Krisnadewi, 2012; Maftukhah, 2013; Santoso, 2001; Siregar \& Yusdiana, 2014; Yuniarti, 2013). 
For financial performance variables (ROA) and firm value, no significant difference is found, meaning that companies with managerial ownership and managerial non-ownership companies have average financial performance and firm value that are almost the same even though in the descriptive data in the table. 1 shows companies with managerial ownership have higher financial performance and firm value compared to companies with non-managerial ownership. This proves that managers as well as shareholders when increasing company performance and company value, the value of their wealth as individuals will also increase so that companies with managerial ownership will definitely try to improve financial performance and company value because it will have an impact on the manager's own wealth. Several studies that found a link between managerial ownership and financial performance had previously been studied by (Christiawan \& Tarigan, 2007; Lestari, 2019; Hidayat \& Firmansyah, 2017). Whereas researchers who have conducted research on managerial ownership with firm values include those conducted by (Sukirni, 2012; Sumanti \& Mangantar, 2015; Kuswanto, 2006; Putra \& Wirawati, 2013; Dewi \& Sanica, 2017; Nurkhin, Wahyudin, \& Fajriah, 2017; Putra \& Wirawati, 2013).

\section{Conclusion}

From the results of existing studies it is proven that descriptively debt ratio, financial performance and the value of companies with managerial ownership are higher than non-managerial ownership companies. However, from the results of the statistics test only debt policy variables were found to have significant differences between companies with managerial ownership when compared to companies with non-managerial ownership. Companies with managerial ownership have a level of courage in carrying out debt policies from creditors compared to non-managerial ownership companies that are more careful in conducting debt policies. For the next researcher, it is recommended to use other measures related to debt policy, financial performance and corporate value.

\section{References}

Christiawan, Y. Y., \& Tarigan, J. (2007). Kepemilikan Managerial: Kebijakan Hutang, Kinerja dan NIlai Perusahaan. Jurnal Akuntansi dan Keuangan, 9(1), 1-8.

Dewi, K. R., \& Sanica, I. G. (2017). Pengaruh kepemilikan institusional, kepemilikan manajerial, dan pengungkapan corporate social responsibility terhadap nilai perusahaan pada perusahaan manufaktur yang terdaftar di Bursa Efek Indonesia. Jurnal Ilmiah Akuntansi dan Bisnis Volume, 2(1), 1-26.

Fama, E., \& French, K. (1998). Taxe, financing decision, and firm value. The Journal of Finance, 53(3), 819-843.

Hidayat, I. P., \& Firmansyah, I. (2017). Determinants of financial performance in the Indonesian Islamic insurance industry. Etikonomi, 16(1), 1-12.

Jensen, M. C., \& Meckling, W. H. (1976). Theory Of The Firm: Managerial Behavior, Agency Costs And Ownership Structure. Journal Of Financial Economics 3, 3(1), 305-360.

Kuswanto, A. (2006). Kepemilikan manajerial dan nilai perusahaan. Majalah Ekonomi dan Komputer, 3(1), 119-126. 
Larasati, E. (2011). Pengaruh kepemilikan manajerial, kepemilikan institusional dan kebijakan dividen terhadap kebijakan hutang perusahaan. JURNAL EKONOMI BISNIS, 16(2), 103-107.

Maftukhah, I. (2013). Kepemilikan manajerial, kepemilikan institusional, dan kinerja keuangan sebagai penentu struktur modal perusahaan. Jurnal Dinamika Manajemen, 4(1), 69-81.

Meriani, N., \& Krisnadewi, K. A. (2012). Pengaruh Kondisi Keuangan, Pertumbuhan Perusahaan, Dan Reputasi Auditor Pada Pengungkapan Opini Audit Going Concern. Jurnal Ilmiah Akuntansi dan Bisnis, 7(1), 1-29.

Nurkhin, A., Wahyudin, A., \& Fajriah, A. (2017). Relevansi struktur kepemilikan terhadap profitabilitas dan nilai perusahaan barang konsumsi. Jurnal Akuntansi Multiparadigma JAMAL, 8(1), 3-46.

Putra, I. K., \& Wirawati, N. G. (2013). Pengaruh kepemilikan manajerial terhadap hubungan antara kinerja dengan nilai perusahaan. E-Jurnal Akuntansi Universitas Udayana, 5(3), 639-651.

Santoso, S. (2001). SPSS-Statistik Parametrik. Jakarta: Elek Media Komindo, Kelompok Gramedia.

Schroeder, R. G., Clark, M. W., \& Cathey, J. M. (2001). Accounting Theory and Analysis-Text Cases and Readings 7th Edition. New York: John Wiley.

Siregar, H., \& Yusdiana. (2014). Pengaruh kepemilikan manajerial, kepemilikan institusional, resiko bisnis, profitabilitas, ukuran perusahaan terhadap kebijakan hutang dan kebijakan dividen serta pengaruhnya terhadap nilai perusahaan yang dimoderasi oleh corporate governance. Jurnal Manajemen Bisnis STIE IBBI, 21(2), 1-20.

Sukirni, D. (2012). Kepemilikan manajerial, kepemilikan institusional, kebijakan deviden dan kebijakan hutang analisis terhadap nilai perusahaan. Accounting Analysis Journal, 1(2), 1-12.

Sumanti, J. C., \& Mangantar, M. (2015). Analisis kepemilikan manajerial, kebijakan hutang dan profitabilitas terhadap kebijakan dividen dan nilai perusahaan pada perusahaan manufaktur yang terdaftar di BEI. Jurnal EMBA, 3(1), 1141-1151.

Yuniarti, A. (2013). Pengaruh kepemilikan manajerial, dividen, profitabilitas dan struktur aset terhadap kebijakan hutang. Accounting Analysis Journal, 2(4), 447-554. 